\title{
GAMBARAN PERSEPSI PASIEN INSTALASI RAWAT INAP MENGENAI BRAND EQUITY RUMAH SAKIT TINGKAT III BALADHIKA HUSADA JEMBER TAHUN 2018
}

\author{
(Description of Inpatient's Perception about Brand Equity of Baladhika Husada \\ Jember Third-Level Hospital in 2018)
}

\author{
${ }^{1}$ Dwi Novita Sari, ${ }^{2}$ Christyana Sandra, ${ }^{3}$ Sri Utami \\ ${ }^{123}$ Bagian Administrasi dan Kebijakan Kesehatan \\ Fakultas Kesehatan Masyarakat Universitas Jember \\ Email: christyana sandra@yahoo.com
}

\begin{abstract}
Brand equity is a set of brand assets and liabilities linked to a brand name and symbol, which add to or subtract from the value provided by a product or service. For 3 years, Bed Occupancy Rate haven't met the optimal standard and shows that the society is still less utilize inpatient services of Baladhika Husada Jember Third-Level Hospital. The objective of this study was describe inpatient's perception about brand equity of Baladhika Husada Jember Third-Level Hospital in 2018. This study used a descriptive study. Results showed that most of the respondents are female, in the age group $>45$ years old, living in Jember, last education are elementary school/equivalent, housewifes, family income ranged between $R p$ 1.1 million - Rp 2 million and methods of payment using BPJS Health insurance. Variable brand awareness is good enough because the majority of respondents choose Baladhika Husada Jember Third-Level Hospital as top of mind. Brand association through product attributes, intangible, customer benefits, relative price, and use/application are in good category. Perceived quality through performance, serviceability, reliability, features, conformance to specifications and results are in good category. Brand loyalty dominated by satisfied buyer.
\end{abstract}

Keywords: Perception, Inpatient, Brand Equity, Hospital

\begin{abstract}
Abstrak
Ekuitas merek adalah serangkaian aset dan kewajiban (liabilities) merek yang terkait dengan sebuah merek, nama, dan simbolnya, yang menambah atau mengurangi nilai yang diberikan sebuah produk atau jasa kepada perusahaan dan/atau pelanggan perusahaan tersebut. Angka Bed Occupancy Rate (BOR) RS Tk. III Baladhika Husada Jember selama 3 tahun tersebut belum memenuhi standar optimal dan menunjukkan bahwa masyarakat masih kurang memanfaatkan pelayanan rawat inap. Tujuan penelitian ini adalah untuk menggambarkan persepsi pasien instalasi rawat inap mengenai brand equity Rumah Sakit Tingkat III Baladhika Husada Jember Tahun 2018. Jenis penelitian ini adalah deskriptif. Hasil penelitian menunjukkan bahwa sebagian besar responden berjenis kelamin perempuan, berada pada kelompok usia $>45$ tahun, bertempat tinggal di Jember, pendidikan terakhir tamat SD/Sederajat, pekerjaan Ibu Rumah Tangga (IRT), penghasilan keluarga berkisar antara Rp 1,1 Juta - Rp 2 Juta dan cara pembayaran pengobatan menggunakan asuransi BPJS Kesehatan. Variabel kesadaran merek sudah cukup baik karena mayoritas responden menjadikan RS Tk. III Baladhika Husada Jember sebagai 123 Dwi Novita Sari, Christyana Sandra, Sri Utami adalah Bagian Administrasi dan Kebijakan Kesehatan Fakultas Kesehatan Masyarakat Universitas Jember
\end{abstract}


puncak pikiran. Berdasarkan asosiasi merek melalui atribut produk, atribut tak berwujud, manfaat bagi pengguna, harga relatif, dan penggunaan/aplikasi sudah dalam kategori baik. Berdasarkan persepsi kualitas melalui kinerja, pelayanan, keandalan, karakteristik produk, kesesuaian dengan spesifikasi dan hasil sudah dalam kategori baik. Berdasarkan loyalitas merek didominasi oleh satisfied buyer (pembeli yang puas dengan biaya peralihan).

Kata Kunci: Persepsi, Pasien Rawat Inap, Ekuitas Merek, Rumah Sakit

\section{PENDAHULUAN}

$\begin{array}{llr}\text { Rumah } & \text { Sakit adalah } & \text { institusi } \\ \text { pelayanan } & \text { kesehatan } & \text { yang }\end{array}$
menyelenggarakan pelayanan kesehatan perorangan secara paripurna yang menyediakan pelayanan rawat inap, rawat jalan, dan gawat darurat [37]. Pertumbuhan rumah sakit di Indonesia menunjukkan peningkatan pada kurun waktu 2013 sampai dengan 2015. Jumlah rumah sakit di Indonesia pada tahun 2013 sebanyak 2.228 unit, tahun 2014 sebanyak 2.406 unit, dan pada tahun 2015 sebanyak 2.448 unit[17]. Pertumbuhan rumah sakit ini menimbulkan kompetisi yang semakin ketat dan pelanggan semakin mempunyai pilihan yang selektif, dan ini merupakan tantangan yang akan mempengaruhi keberlanjutan organisasi [26].

Salah satu upaya Rumah Sakit dalam membangun kesetiaan pelanggan adalah dengan membangun merek yang kuat, yang akan memunculkan kesetiaan merek pada pelanggan [28]. Kesetiaan pelanggan pada sebuah merek, menuntut rumah sakit untuk selalu memperhatikan merek yang dimilikinya, karena merek yang kuat merupakan aset yang dimiliki untuk mendapatkan posisi teratas di benak konsumen/pelanggan [3].

Salah satu cara untuk memiliki merek yang kuat adalah dengan memperkuat elemen-elemen brand equity [24]. Brand equity adalah serangkaian aset dan kewajiban (liabilities) merek yang terkait dengan sebuah merek, nama, dan simbolnya, yang menambah atau mengurangi nilai yang diberikan sebuah produk atau jasa kepada perusahaan dan/atau pelanggan perusahaan tersebut [1]. Brand equity yang kuat dapat menghilangkan keraguan konsumen terhadap kualitas merek [20]. Untuk mengetahui kekuatan merek di lakukan pengukuran terhadap empat dimensi brand equity yang terdiri dari brand awareness (kesadaran merek), brand association (asosiasi merek), perceived quality (persepsi kualitas), dan brand loyalty (loyalitas merek) [1]. Pengukuran dampak branding dilakukan berdasarkan perspektif psikologi konsumen (yaitu psikologi kognitif) dalam pengembangan model keputusan konsumen berkenaan dengan merek [35].

Kabupaten Jember mempunyai 12 rumah sakit yang terdiri dari 9 rumah sakit umum dan 4 rumah sakit khusus [8]. Dari 9 rumah sakit umum tersebut, lokasi 5 rumah sakitnya saling berdekatan dan merupakan rumah sakit rujukan fasilitas kesehatan tingkat pertama (FKTP). Lima rumah sakit tersebut adalah RSU Kaliwates, RS Jember Klinik, RS Citra Husada, RS Bina Sehat dan RS Tk. III Baladhika Husada Jember. Dengan adanya Jaminan Kesehatan Nasional saat ini telah memudahkan masyarakat, khususnya masyarakat miskin untuk mendapatkan 


\begin{tabular}{|c|c|c|}
\hline Karakteristik Responden & $\mathbf{n}$ & $\%$ \\
\hline \multicolumn{3}{|l|}{ Usia } \\
\hline$<17$ tahun & 0 & 0 \\
\hline 17-25 tahun & 10 & 11,8 \\
\hline 26-35 tahun & 17 & 20 \\
\hline 36-45 tahun & 17 & 20 \\
\hline$>45$ tahun & 41 & 48,2 \\
\hline \multicolumn{3}{|l|}{ Kota Tempat Tinggal } \\
\hline Jember & 79 & 92,9 \\
\hline Lumajang & 1 & 1,2 \\
\hline Bondowoso & 1 & 1,2 \\
\hline Banyuwangi & 3 & 3,5 \\
\hline Situbondo & 0 & 0 \\
\hline Lainnya & 1 & 1,2 \\
\hline \multicolumn{3}{|l|}{ Pendidikan Terakhir } \\
\hline Tidak/belum pernah sekolah & 5 & 5,9 \\
\hline Tidak Tamat SD & 3 & 3,5 \\
\hline Tamat SD/Sederajat & 24 & 28,2 \\
\hline Tamat SMP/Sederajat & 20 & 23,5 \\
\hline Tamat SMA/Sederajat & 20 & 23,5 \\
\hline Tamat Perguruan Tinggi & 13 & 15,3 \\
\hline \multicolumn{3}{|l|}{ Pekerjaan } \\
\hline Pelajar/Mahasiswa & 3 & 3,5 \\
\hline Pegawai Negeri & 8 & 9,4 \\
\hline Pegawai Swasta & 7 & 8,2 \\
\hline Wiraswasta/ Pengusaha & 19 & 22,4 \\
\hline IRT (Ibu Rumah Tangga & 34 & 40 \\
\hline Pensiunan & 4 & 4,7 \\
\hline Lain-lain & 10 & 11,8 \\
\hline \multicolumn{3}{|l|}{ Penghasilan Keluarga } \\
\hline$<$ Rp 1 Juta & 29 & 34,1 \\
\hline Rp 1,1 Juta - Rp 2 Juta & 33 & 38,8 \\
\hline Rp 2,1 Juta - Rp 4 Juta & 20 & 23,5 \\
\hline Rp 5 Juta - Rp 10 Juta & 2 & 2,4 \\
\hline$>$ Rp 10 Juta & 1 & 1,2 \\
\hline \multicolumn{3}{|l|}{ Cara Pembayaran Pengobatan } \\
\hline BPJS Kesehatan & 76 & 89,4 \\
\hline BPJS Ketenagakerjaan & 0 & 0 \\
\hline Asuransi lainnya & 0 & 0 \\
\hline Biaya sendiri (out of pocket) & 9 & 10,6 \\
\hline
\end{tabular}

Tabel 1 menunjukkan bahwa dari 85 responden yang memanfaatkan pelayanan rawat inap di RS Tk. III Baladhika Husada Jember sebagian besar berjenis kelamin perempuan yaitu
(71,8\%), sebagian besar berada pada kelompok usia $>45$ tahun (48,2\%), bertempat tinggal di Jember (92,9\%), pendidikan terakhir sebagian besar responden merupakan tamat 
SD/Sederajat $(28,2 \%)$, jenis pekerjaan sebagian besar responden merupakan Ibu Rumah Tangga (IRT) (40\%), penghasilan keluarga sebagian besar responden berkisar antara Rp 1,1 Juta Rp 2 Juta (38,8\%), dan mayoritas responden menggunakan asuransi BPJS Kesehatan $(89,4 \%)$.

\section{Brand Awareness}

Tabel 2. Distribusi Responden berdasarkan Brand Awareness

\begin{tabular}{lcc}
\hline Brand Awareness & $\mathbf{n}$ & $\mathbf{\%}$ \\
\hline Top of Mind & 42 & 49,4 \\
Brand Recall & 17 & 20 \\
Brand Recognition & 26 & 30,6 \\
Unaware of Brand & 0 & 0 \\
\hline Total & 85 & 100 \\
\hline
\end{tabular}

Tabel 2 menunjukkan bahwa bahwa dari 85 responden sebagian besar mengingat RS Tk. III Baladhika Husada Jember sebagai top of mind $(49,4 \%)$. RS Tk. III Baladhika Husada Jember disebutkan pertama kali oleh konsumen atau yang pertama kali muncul dalam benak konsumen. Selanjutnya, responden yang menjadikan RS Tk. III Baladhika Husada Jember sebagai brand recall (20\%). Pada tingkatan ini responden mengingat kembali brand rumah sakit tanpa bantuan (unaided recall) dan pelanggan mampu mengingat merek tanpa diberikan stimulus. Selanjutnya, responden yang menjadikan RS Tk. III Baladhika Husada Jember sebagai brand recognition $(30,6 \%)$. Pada tingkatan ini pengenalan suatu brand muncul lagi setelah dilakukan pengingatan kembali lewat bantuan (aided recall). Kemudian, tidak ada seorang responden $(0 \%)$ yang tidak menyadari RS Tk. III Baladhika Husada Jember.

\section{Brand Association}

Tabel 3. Distribusi Responden berdasarkan Brand Association

\begin{tabular}{lcc}
\hline Brand Association & n & \% \\
\hline Atribut Produk & & 54,1 \\
\hline Baik & 46 & 45,9 \\
Cukup Baik & 39 & 0 \\
Kurang Baik & 0 & \\
\hline Atribut Tak Berwujud & & 95,3 \\
\hline Baik & 81 & 4,7 \\
Cukup Baik & 4 & 0 \\
Kurang Baik & 0 & 91,8 \\
\hline Manfaat Bagi Pengguna & & 8,2 \\
\hline Baik & 78 & 0 \\
Cukup Baik & 7 & \\
Kurang Baik & 0 & \\
\hline
\end{tabular}




\begin{tabular}{lcc}
\hline Brand Association & n & \% \\
\hline Harga Relatif & & 100 \\
\hline Baik & 85 & 0 \\
Cukup Baik & 0 & 0 \\
Kurang Baik & 0 & \\
\hline Penggunaan/Aplikasi & & 100 \\
\hline Baik & 85 & 0 \\
Cukup Baik & 0 & 0 \\
Kurang Baik & 0 & \\
\hline
\end{tabular}

Tabel 3 menunjukkan bahwa sebagian besar responden menilai asosiasi merek berdasarkan atribut produk di Instalasi Rawat Inap RS Tk. III Baladhika Husada Jember sudah baik $(54,1 \%)$ dan cukup baik $(45,1 \%)$. Mayoritas responden menilai asosiasi merek berdasarkan atribut tak berwujud sudah baik $(95,3 \%)$ dan cukup baik
$(4,7 \%)$. Mayoritas responden menilai asosiasi merek berdasarkan manfaat bagi pengguna sudah baik $(91,8 \%)$ dan cukup baik $(8,2 \%)$. Seluruh responden menilai asosiasi merek berdasarkan harga relatif sudah baik (100\%). Seluruh responden menilai asosiasi merek berdasarkan penggunaan/aplikasi sudah baik (100\%).

\section{Perceived Quality}

Tabel 4. Distribusi Responden berdasarkan Perceived Quality

\begin{tabular}{lcc}
\hline Perceived Quality & n & \% \\
\hline Kinerja & 70 & 82,4 \\
\hline Baik & 15 & 17,6 \\
Cukup Baik & 0 & 0 \\
Kurang Baik & & 100 \\
\hline Pelayanan & 85 & 0 \\
\hline Baik & 0 & 0 \\
Cukup Baik & 0 & \\
Kurang Baik & & 91,8 \\
\hline Karakteristik Produk & 78 & 0 \\
\hline Baik & 7 & 81,2 \\
Cukup Baik & 0 & 18,8 \\
Kurang Baik & & 0 \\
\hline Keandalan & 69 & \\
\hline Baik & 16 & 98,8 \\
Cukup Baik & 0 & 1,2 \\
Kurang Baik & & 0 \\
\hline Kesesuaian dengan Spesifikasi & 84 & \\
\hline Baik & 1 & 98,8 \\
Cukup Baik & 0 & \\
Kurang Baik & & \\
\hline Hasil & 84 & \\
\hline Baik & & \\
& & \\
\hline & & \\
\hline
\end{tabular}




\begin{tabular}{ccc}
\hline Perceived Quality & n & $\mathbf{\%}$ \\
\hline Cukup Baik & 1 & 1,2 \\
Kurang Baik & 0 & 0 \\
\hline
\end{tabular}

Tabel 4 menunjukkan bahwa mayoritas responden menilai persepsi pelanggan terhadap keseluruhan kualitas kinerja di Instalasi Rawat Inap RS Tk. III Baladhika Husada Jember sudah baik yaitu $(82,4 \%)$ dan cukup baik $(17,6 \%)$. Seluruh responden menilai bahwa persepsi pelanggan terhadap keseluruhan kualitas pelayanan sudah baik (100\%). Mayoritas responden menilai bahwa persepsi pelanggan terhadap keseluruhan kualitas karakteristik produk sudah baik $(91,8 \%)$ dan cukup baik (8,2\%). Mayoritas responden menilai bahwa persepsi pelanggan terhadap keseluruhan kualitas keandalan sudah baik $(81,2 \%)$ dan cukup baik (18,8\%). Mayoritas responden menilai bahwa persepsi pelanggan terhadap keseluruhan kualitas kesesuaian dengan spesifikasi sudah baik $(98,8 \%)$ dan cukup baik (1,2\%). Mayoritas responden menilai bahwa persepsi pelanggan terhadap keseluruhan kualitas hasil sudah baik $(98,8 \%)$ dan cukup baik $(1,2 \%)$.

\section{Brand Loyalty}

Tabel 5. Distribusi Responden berdasarkan Brand Loyalty

\begin{tabular}{lcc}
\hline Brand Loyalty & $\mathbf{n}$ & $\mathbf{\%}$ \\
\hline Switcher/Price Buyer & & \\
\hline Rendah & 80 & 94,1 \\
Tinggi & 5 & 5,9 \\
\hline Habitual Buyer & & \\
\hline Tinggi & 74 & 87,1 \\
Rendah & 11 & 12,9 \\
\hline Satiesfied Buyer & & \\
\hline Tinggi & 82 & 96,5 \\
Rendah & 3 & 3,5 \\
\hline Likes The Brand & & \\
\hline Tinggi & 79 & 92,9 \\
Rendah & 6 & 7,1 \\
\hline Committed Buyer & & 89,4 \\
\hline Tinggi & 76 & 10,6 \\
Rendah & 9 & \\
\hline
\end{tabular}

Tabel 5 menunjukkan bahwa sebanyak 80 respoden $(94,1 \%)$ memilih tidak akan mengganti RS Tk. III Baladhika Husada Jember karna faktor harga dan mutu layanan pesaing yang lebih baik. Sedangkan sebanyak 5 responden (5,9\%) memilih akan mengganti RS Tk. III Baladhika Husada
Jember karna faktor harga dan mutu layanan pesaing yang lebih baik. Hal ini menunjukkan bahwa konsumen yang kecenderungan perpindahan merek karena faktor harga di RS Tk. III Baladhika Husada Jember rendah. Selanjutnya, habitual buyer di Instalasi Rawat Inap RS Tk.III Baladhika Husada 
Jember tinggi (87,1\%). Selanjutnya, satisfied buyer di Instalasi Rawat Inap RS Tk. III Baladhika Husada Jember sudah tinggi $(96,5,9 \%)$. Selanjutnya, likes the brand di Instalasi Rawat Inap RS Tk. III Baladhika Husada Jember sudah tinggi (92,9\%). Kemudian, commited buyer di Instalasi Rawat Inap RS Tk.III Baladhika Husada Jember sudah tinggi $(89,4 \%)$.

\section{PEMBAHASAN}

\section{Distribusi Responden berdasarkan Karakteristik Individu di Instalasi Rawat Inap RS Tk. III Baladhika Husada Jember}

Hasil penelitian menunjukkan bahwa sebagian besar responden yang memanfaatkan pelayanan rawat inap di RS Tk.III Baladhika Husada Jember merupakan perempuan. Perempuan pada umumnya lebih banyak melaporkan gejala sakit dan lebih cepat menginginkan untuk mendapatkan pelayanan kesehatan ketika sakit dibandingkan dengan laki-laki [28]. Sebuah survei nasional di Amerika Serikat tahun 2006 yang menunjukkan bahwa wanita memiliki peran penting sebagai penentu keputusan dalam pelayanan kesehatan, tidak hanya bagi dirinya sendiri tetapi juga bagi keluarganya [19]. Berdasarkan karakteristik usia, sebagian besar pasien berada pada kelompok usia $>45$ tahun. Seiring dengan bertambahnya usia seseorang dapat berpengaruh pada kesehatannya, dimana terjadi kemunduran struktur dan fungsi organ, sehingga masyarakat yang berusia lebih tua lebih cenderung banyak memanfaatkan pelayanan kesehatan dibandingkan dengan usia muda [11].

Berdasarkan karakteristik responden menurut kota tempat tinggal, mayoritas pasien merupakan masyarakat
Jember. Seseorang yang bertempat tinggal jauh dari fasilitas pelayanan kesehatan cenderung tidak puas terhadap kualitas pelayanan dibandingkan dengan yang bertempat tinggal dekat. Namun, apabila pasien mengetahui kualitas pelayanan dalam suatu rumah sakit itu baik, maka pasien akan rela menempuh jarak yang jauh untuk datang berobat ke rumah sakit tersebut [14].

Berdasarkan karakteristik pendidikan terakhir, sebagian besar pasien merupakan tamat SD/Sederajat. Lumenta menyatakan bahwa seseorang dengan tingkat pendidikan yang rendah, ia cenderung lebih banyak menerima karena tidak tahu apa yang dibutuhkannya, asal sembuh saja itu sudah cukup baginya [2].Berdasarkan karakteristik jenis pekerjaan, sebagian besar merupakan Ibu Rumah Tangga (IRT). Lumenta menyatakan kelompok masyarakat yang bekerja cenderung dipengaruhi oleh lingkungan pekerjaan juga lingkungan keluarga. Hal ini ada hubungannya dengan teori yang menyatakan bahwa seseorang yang bekerja cenderung lebih banyak menuntut atau mengkritik terhadap pelayanan yang diterimanya jika memang tidak merasa puas bagi dirinya dibandingkan dengan yang tidak bekerja [2].

Berdasarkan karakteristik penghasilan keluarga, sebagian besar pasien memiliki penghasilan keluarga berkisar antara Rp 1,1 Juta - Rp 2 Juta. Lumenta menyatakan bahwa faktor ekonomi sebenarnya menjadi penyebab utama naik dan turunnya tingkat pemanfaatan fasilitas pelayanan kesehatan. Dengan kata lain, semakin tinggi penghasilan yang diperoleh maka semakin tinggi pula harapan atau keinginan yang lebih, namun faktor ini tidak mutlak demikian adanya, tidak 
terlepas dari sesuatu hal yang mempengaruhinya [2]. Berdasarkan karakteristik cara pembayaran pengobatan, mayoritas pasien menggunakan asuransi BPJS Kesehatan. Menurut penelitian Kurniawan menyatakan bahwa seseorang dengan status pembiayaan askes/jamkesmas memiliki tingkat kepuasan yang lebih tinggi dibandingkan dengan yang status pembiayaan nya umum [19]. Di dalam pelayanan kesehatan, seseorang yang membayar pelayanan akan cenderung lebih banyak menuntut terhadap pelayanan yang ada (tidak mudah puas) dibandingkan dengan seseorang yang tidak membayar atau membayar lebih ringan[2].

\section{Brand Awareness}

Berdasarkan hasil penelitian didapatkan sebanyak 49,4\% menjadikan RS Tk. III Baladhika Husada Jember sebagai top of mind, $20 \%$ sebagai brand recall, 30,6\% brand recognition, dan 0\% unaware of brand. Hal ini menggambarkan bahwa kesadaran pelangggan terhadap RS Baladhika Husada Jember adalah cukup baik karena 49,4\% responden menyadari merek RS Tk. III Baladhika Husada Jember tanpa bantuan, $50,6 \%$ responden menyadari merek RS Tk. III Baladhika Husada Jember dengan bantuan dan tidak ada seorang responden yang tidak menyadari RS Tk. III Baladhika Husada Jember. Hal ini disebabkan karena pasien telah cukup lama tinggal ( $\geq 2$ hari) di rumah sakit ini, sehingga menimbulkan kesan yang cukup melekat pada pasien.

Yang perlu menjadi perhatian RS Tk. III Baladhika Husada Jember adalah bahwa jumlah respoden yang menempatkan RS Tk. III Baladhika Husada Jember pada tingkatan brand recall dan brand recognition. Pelanggan yang menempati posisi ini sangat mungkin untuk memilih rumah sakit lain saat mereka memerlukan layanan kesehatan, oleh karena itu rumah sakit perlu memperhatikan pelanggan dalam kelompok ini [24]. Karena kesadaran menyediakan merek dengan rasa keakraban/dikenal, dan orang menyukai hal yang dikenal/akrab [1].

\section{Brand Association}

a. Atribut Produk

Berdasarkan hasil penelitian, responden menilai asosiasi merek berdasarkan atribut produk RS Tk. III Baladhika Husada Jember baik yaitu $(56,5 \%)$ dan cukup baik $(43,5 \%)$. Seluruh responden menyatakan setuju bahwa RS Tk. III Baladhika Husada Jember memiliki lokasi yang mudah diakes. Lokasi merupakan faktor yang sangat penting sehingga pasien ingin berobat di rumah sakit ketika sakit. Mills Gilson mengungkapkan bahwa semakin jauh jarak pusat pelayanan kesehatan atau rumah sakit dari tempat tinggal masyarakat akan menurunkan permintaan terhadap pelayanan kesehatan [22].

Selanjutnya, mayoritas responden menyatakan setuju bahwa RS Tk. III Baladhika Husada Jember memiliki ruang tunggu pasien yang nyaman serta memiliki fasilitas kamar yang memberikan kenyamanan pada pasien. Pelanggan menyatakan bahwa meskipun fasilitas kamar kelas III merupakan kamar yang berisi beberapa tempat tidur namun masih dapat memberi kenyamanan dan privasi karena masingmasing tempat tidur dipisah dengan tirai pembatas. Namun, sebanyak 4 responden menyatakan ketidaksetujuan karena bel pemanggil perawat yang tidak ada dan AC (Air Conditioner) di ruangan paviliun yang sempat tidak berfungsi dengan baik. Ruangan yang bersih dan 
nyaman akan memberikan nilai tambah bagi rumah sakit. Ruang rawat inap seharusnya membangkitkan optimisme sehingga dapat membantu proses penyembuhan pasien [25].

Selanjutnya, sebagian besar responden menyatakan setuju bahwa RS Tk. III Baladhika Husada Jember memiliki bangunan rumah sakit yang terlihat modern. Namun, sebanyak 27 responden menyatakan ketidaksetujuan karena masih terdapat beberapa bangunan rawat inap yang merupakan bangunan kuno. Fisik merupakan suatu hal yang sangat penting bagi sebuah rumah sakit karena bangunan yang indah, fungsional, efisien dan bersih memberikan kesan yang positif bagi seluruh pengguna rumah sakit [25]. Rancangan fisik rumah sakit dapat mempengaruhi pilihan, harapan, serta perilaku konsumen [12].

Kemudian, sebagian besar responden menyatakan setuju bahwa RS Tk. III Baladhika Husada Jember memiliki fasilitas parkir luas. Namun, sebanyak 40 responden menyatakan tidak setuju karena beberapa pelanggan ataupun keluarga merasa kesulitan saat hendak memarkir kendaraan khususnya mobil ketika ingin mengunjungi pasien. Jika tempat parkir penuh pelanggan ataupun keluarga terpaksa memarkir kendaraan mobilnya di tepi jalan. Permasalahan parkir terjadi apabila jumlah kebutuhan parkir lebih besar daripada kapasitas parkir yang ada. Sehingga kendaraan yang tidak tertampung pada tempat parkir akan mengganggu kelancaran arus lalu lintas pada ruas jalan di sekitarnya [13].

\section{b. Atribut Tak Berwujud}

Berdasarkan hasil penelitian, responden menilai bahwa asosiasi atau kesan yang timbul dalam benak pelanggan berdasarkan atribut tak berwujud RS Tk. III Baladhika Husada Jember sudah baik (95,3\%). Seluruh responden menyatakan setuju bahwa RS Tk. III Baladhika Husada Jember memiliki citra rumah sakit yang sangat baik. Keberhasilan perusahaan membentuk citra masyarakat, dipengaruhi oleh beberapa faktor misalnya sejarah perusahaan, kelengkapan sarana dan prasarana, dan keberhasilan dalam memberikan pelayanan kepada pasien [39]. Pelanggan menyebutkan bahwa RS Tk. III Baladhika Husada Jember dikenal sebagai rumah sakit yang telah terakreditasi paripurna, memiliki layanan unggulan kemoterapi serta memiliki dokter bedah ortopedi dan traumatologi yang baik.

Selanjutnya, seluruh responden menyatakan setuju bahwa RS Tk. III Baladhika Husada Jember memiliki dokter dan perawat RS Tk. III Baladhika Husada Jember bekerja secara profesional. Pelanggan menyatakan bahwa RS Tk. III Baladhika Husada Jember memiliki dokter yang berpengalaman, ramah, perhatian, memberikan diagnosa yang tepat dan juga dokter memberikan pemeriksaan dengan sungguh-sungguh. Sebagian besar tenaga di rumah sakit adalah tenaga profesional dan sebagian besar diantara mereka adalah dokter dan perawat. Indikator yang ditampilkan untuk profesionalisme perawat mirip dengan profesionalisme dokter yaitu pengetahuan dan pengalaman yang baik mengenai produk, keterampilan dalam menjalankan tugas dan kemampuan berkomunikasi [9].

Selanjutnya, seluruh responden menyatakan setuju bahwa RS Tk. III Baladhika Husada Jember menyediakan layanan kesehatan yang mengutamakan keselamatan pasien dan memiliki layanan kesehatan yang terpercaya. Seiring dengan perkembangan teknologi 
dan informasi, pelanggan memilih layanan kesehatan tidak hanya faktor seorang dokter tetapi juga mementingkan kualitas pelayanan dan mutu pelayanan yang selalu mengutamakan keselamatan pasien [23].

Kemudian, mayoritas responden menyatakan setuju bahwa RS Tk. III Baladhika Husada Jember memberikan pelayanan kesehatan yang memuaskan. Namun, sebanyak 5 responden menyatakan tidak setuju karena pelanggan merasa kurang puas dengan pelayanan yang diberikan dan pelanggan membandingkan pelayanan kesehatan yang diberikan rumah sakit lain lebih baik daripada pelayanan yang diterima saat dirawat di RS Tk. III Baladhika Husada Jember. Pelayanan rumah sakit yang kurang memuaskan yaitu keramahan dan keandalan perawat dalam melayani pasien. Kepuasan pasien merupakan cerminan kualitas pelayanan kesehatan yang mereka terima [5]. Pada umumnya pasien tidak dapat menilai kompetensi teknis, sehingga mereka menilai mutu layanan dari karakteristik nonteknis atau hubungan interpersonal dan kenyamanan pelayanan [31].

\section{c. Manfaat Bagi Pengguna}

Hasil penelitian menunjukkan, responden menilai asosiasi merek berdasarkan manfaat bagi pengguna RS Tk. III Baladhika Husada Jember sudah baik (91,8\%). Mayoritas responden menyatakan setuju bahwa RS Tk. III Baladhika Husada Jember memiliki layanan kesehatan yang prima dengan lokasi yang asri. Pelanggan menyebutkan bahwa di setiap gedung perawatan di RS Tk. III Baladhika Husada memiliki taman. Sebuah studi dari Ulrich tentang pengaruh kontak visual terhadap alam secara signifikan sangat menentukan bagi penyembuhan pasien dewasa di dalam rumah sakit [33].
Selanjutnya, mayoritas responden menyatakan setuju bahwa RS Tk. III Baladhika Husada Jember memiliki fasilitas pelayanan kesehatan yang lengkap. Namun, sebanyak 7 responden menyatakan tidak setuju karena beberapa pelanggan memiliki keluhan seperti bel pemanggil perawat yang tidak ada dan tidak adanya kamar mandi untuk pasien di kamar kelas III ruang Teratai. Bel pemanggil perawat di rumah sakit merupakan bentuk upaya meningkatkan kecepatan response time perawat dalam memberikan asuhan langsung kepada pasien [30]. Menurut Pedoman Teknis Bangunan Rumah Sakit Ruang Rawat Inap menyebutkan bahwa jumlah kamar mandi untuk penyandang cacat yaitu 1 buah untuk setiap kelas [16].

\section{d. Harga Relatif}

Hasil penelitian menunjukkan responden menilai asosiasi merek berdasarkan harga relatif RS Tk. III Baladhika Husada Jember sudah baik (100\%). Seluruh pelanggan menyatakan setuju bahwa biaya pengobatan di RS Tk. III Baladhika Husada Jember terjangkau dan sangat mudah untuk menggunakan asuransi BPJS Kesehatan, BPJS Ketenagakerjaan dan asuransi lainnya dalam pembayaran pengobatan selama perawatan. Unsur harga memberikan pengaruh yang relatif. Ada sebagian konsumen yang sensitif terhadap harga, akan tetapi ada juga yang tidak begitu mempertimbangkan harga dalam pengambilan keputusan pembelian produk [29].

\section{e. Penggunaan/Aplikasi}

Hasil penelitian menunjukkan responden menilai asosiasi merek berdasarkan penggunaan/aplikasi di RS Tk. III Baladhika Husada Jember sudah 
baik (100\%). Seluruh pelanggan menyatakan setuju bahwa RS Tk. III Baladhika Husada Jember memiliki papan petunjuk yang jelas dan mudah ditemukan dalam memberikan arahan pada pelanggan, jam besuk pasien yang cukup panjang dan makanan dari instalasi gizi yang beragam.

Papan petunjuk arah (wayfinding) harus dibuat sejelas mungkin baik penulisannya, kode warna, ukuran maupun penempatan letak atau posisi papan tersebut [10]. Pelanggan menyatakan bahwa desain wayfinding RS Tk.III Baladhika Husada Jember sudah dapat terbaca jelas dengan penempatan ketinggian wayfinding yang telah sesuai dengan standar orang Indonesia. RS Tk.III Baladhika Husada Jember memiliki jam kunjungan/besuktidak terlalu ketat dan masih fleksibel yang dibagi menjadi 3 sesi yaitu sesi pagi mulai dari jam 09.00-11.00, sesi sore mulai dari 16.00-18.00 dan sesi malam mulai dari 19.30-21.00. Seluruh responden mengungkapkan bahwa menu makanan dari instalasi gizi yang diberikan setiap hari selalu beragam sehingga pasien tidak merasa jenuh.

\section{Perceived Quality}

a. Kinerja

Hasil penelitian menunjukkan responden menilai persepsi keseluruhan kualitas kinerja di RS Tk. III Baladhika Husada Jember sudah baik $(82,4 \%)$. Seluruh responden menyatakan setuju bahwa RS Tk. III Baladhika Husada Jember melayani pasien dengan baik, petugas pendaftaran menjalankan tugasnya dengan penuh perhatian dan pelayanan administrasi tidak menyulitkan. Dapat dikatakan bahwa disinilah pelayanan pertama kali yang diterima oleh seorang pasien tiba dirumah sakit. Tata cara melayani pasien dapat dinilai baik bilamana dilaksanakan oleh petugas dengan sikap yang ramah, sopan, tertib dan penuhi tanggung jawab [8].

Selanjutnya, mayoritas responden menyatakan setuju bahwa karyawan RS Tk. III Baladhika Husada Jember mengucapkan salam sebelum melayani pasien. Namun, sebanyak 15 responden menyatakan tidak setuju karena terkadang perawat atau petugas cleaning service langsung masuk ruang rawat inap tanpa mengucapkan salam. Sikap dan perilaku petugas kesehatan dalam memberikan pelayanan berpengaruh pada proses pelayanan, dimana sikap atau perilaku yang baik dalam pada saat memberikan pelayanan dapat memberikan rasa nyaman terhadap pasien [15].

\section{b. Pelayanan}

Hasil penelitian menunjukkan responden menilai persepsi keseluruhan kualitas pelayanan di RS Tk. III Baladhika Husada Jember sudah baik (100\%). Seluruh pelanggan menyatakan setuju bahwa dokter RS Tk. III Baladhika Husada Jember memberikan pemeriksaan pasien dengan sopan, pelayanan medis dilakukan oleh dokter sesuai dengan jenis penyakit, pasien mendapat informasi yang jelas dari dokter mengenai kesehatan pasien, dokter memberikan penjelasan yang rinci atas tindakan yang akan dilakukan terhadap pasien.

Berdasarkan hasil penelitian Wulandari ada hubungan positif yang sangat signifikan antara komunikasi dokter-pasien dengan kepuasan pasien rawat inap. Artinya semakin tinggi semakin tinggi komunikasi dokter-pasien maka akan semakin tinggi pula kepuasan pasien; demikian sebaliknya. Seorang pasien khususnya pasien rawat inap dapat merasa puas jika seorang dokter mampu berkomunikasi secara baik 
dengan pasien. Seorang dokter harus memiliki sikap keterbukaan, empati, dan sikap mendukung yang merupakan aspek komunikasi efektif dari seorang dokter kepada pasien. Ketika seorang dokter bersedia untuk berkata jujur, mampu memahami apa yang sedang dialami seorang pasien dan dapat bersikap mendukung yang ditunjukkan dengan mau memberikan motivasi kepada seorang pasien maka kepuasan yang dirasakan oleh pasien tinggi [38].

$$
\text { Selanjutnya, }
$$
mayoritas responden menyatakan setuju bahwa perawat dengan baik menjelaskan proses keperawatan selama proses perawatan berlangsung. Dengan membangun komunikasi yang baik dengan pasien, ketika perawat memberikan penjelasan tentang tindakan yang akan dilakukan, perawat tidak memberikan kesan memaksakan suatu tindakan kepada pasien apabila pasien tidak bersedia [23].

\section{c. Karakteristik Produk}

Hasil penelitian menunjukkan responden menilai persepsi keseluruhan kualitas karakteristik produk di RS Tk. III Baladhika Husada Jember sudah baik (91,8\%). Mayoritas responden menyatakan setuju bahwa RS Tk. III Baladhika Husada menyediakan fasilitas umum seperti musholla, kafetaria dan minimarket. Namun, sebanyak 8 responden menyatakan ketidaksetujuan karena rumah sakit tidal memiliki gerai ATM di dalam lingkungan rumah sakit. Selanjutnya, seluruh responden menyatakan setuju bahwa ketersediaaan obat-obatan di apotek RS Tk. III Baladhika Husada Jember sangat lengkap. Persediaan obat-obatan harus disesuaikan dengan besarnya kebutuhan masyarakat sekitar karena persediaan obat-obatan yang tidak lancar akan menghambat pelayanan kesehatan [21]. d. Keandalan

Hasil penelitian menunjukkan responden menilai persepsi keseluruhan kualitas keandalan di RS Tk. III Baladhika Husada Jember sudah baik $(81,2 \%)$. Seluruh responden menyatakan setuju bahwa RS Tk. III Baladhika Husada Jember memiliki customer service yang dapat dihubungi selama 24 jam, laboratorium dan radiologi yang terpercaya, pelayanan administrasi cepat, dokter memberikan penjelasan yang meyakinkan saat pemeriksaan, dan perawat telah berusaha sebaik mungkin untuk menolong pasien selama proses perawatan berlangsung.

$$
\text { Selanjutnya, mayoritas }
$$
responden menyatakan setuju bahwa perawat cepat tanggap dalam menangani keluhan pasien. Pelanggan mengungkapkan bahwa perawat sudah cepat tanggap ketika pelanggan mengeluhkan bahwa kerabat pasien lain yang gaduh. Namun, sebanyak 14 responden memiliki keluhan yaitu ketika malam pada hari sabtu dan minggu, perawat tidak dalam keadaan siaga. Keluhan lainnya yaitu perawat tidak langsung datang ketika pelanggan menekan bel pemanggil perawat, sehingga pasien terpaksa menunggu perawat datang atau pendamping pasien harus ke nurse station untuk meminta bantuan perawat saat keadaan darurat.

Kemudian, beberapa pelanggan menyatakan tidak setuju bahwa dokter datang tepat waktu. Ketidaktepatan janji pada jam visite dokter mengakibatkan pasien perlu menunggu visite dokter. Kegiatan menunggu ini sangat merugikan waktu pasien, dan menimbulkan rasa bosan, jenuh bahkan mengakibatkan stress bagi pelanggan yang terpaksa harus menunggu lama [36]. 
e. Kesesuaian dengan Spesifikasi

Hasil penelitian menunjukkan responden menilai persepsi keseluruhan kualitas kesesuaian dengan spesifikasi di RS Tk.III Baladhika Husada Jember sudah baik (98,8\%). Mayoritas pelanggan menyatakan setuju bahwa ketika berobat di RS Tk. III Baladhika Husada Jember pelanggan mendapat perhatian dan pelayanan yang lebih dari yang diharapkan serta memberikan pelayanan yang adil tanpa memandang status sosial. Berdasarkan hasil penelitian Tarmedi, terdapat hubungan yang signifikan antara kesesuaian dengan spesifikasi dengan keputusan pembelian. Kesesuaian dengan spesifikasi produk akan sangat berpengaruh terhadap keputusan pembelian konsumen jika didukung oleh kinerja produk dan karakteristik produk yang baik [34].

\section{f. Hasil}

Hasil penelitian menunjukkan responden menilai bahwa persepsi keseluruhan kualitas hasil di RS Tk.III Baladhika Husada Jember sudah baik (98,8\%). Mayoritas pelanggan menyatakan setuju bahwa pelanggan merasakan adanya manfaat yaitu keadaan pasien menjadi lebih baik setelah menjalani perawatan di RS Tk.III Baladhika Husada Jember. Selanjutnya, pelanggan menyatakan setuju bahwa hasil pemeriksaan (uji laboratorium dan radiologi) di RS Tk. III Baladhika Husada Jember akurat dan diterima pasien dalam waktu yang cepat.

\section{Brand Loyalty}

\section{a. Switcher/price buyer}

Hasil penelitian menunjukkan bahwa switcher/price buyer di RS Tk. III Baladhika Husada Jember rendah (5,9\%). Sebanyak 5 responden memilih akan mengganti RS Tk. III Baladhika Husada Jember karna faktor harga dan mutu layanan pesaing yang lebih baik. Ini merupakan hal yang sangat baik bagi perusahaan sekaligus merupakan keuntungan bagi rumah sakit. Karena semakin tinggi frekuensi pelanggan untuk memindahkan pembeliannya dari suatu merek ke merek yang lain mengindikasikan mereka sebagai pembeli yang sama sekali tidak loyal atau tidak tertarik pada merek tersebut [35].

\section{b. Habitual buyer}

Hasil penelitian menunjukkan bahwa habitual buyer di RS Tk. III Baladhika Husada Jember tinggi $(87,1 \%)$. Mayoritas responden menyatakan setuju bahwa pelanggan merasa puas dengan pelayanan yang diberikan rumah sakit. Selanjutnya, sebagian besar responden menyatakan bahwa tidak akan berpindah ke rumah sakit lain karena membutuhkan biaya peralihan (switching cost) seperti usaha, waktu, uang, maupun pengorbanan lain. Kemudian, sebagian besar responden menjadikan RS Tk. III Baladhika Husada Jember sebagai kebiasaan keluarga saat membutuhkan layanan kesehatan. Pada habitual buyer tidak didapati alasan yang cukup untuk menciptakan keinginan untuk membeli merek produk yang lain atau berpindah merek terutama jika peralihan tersebut memerlukan usaha, biaya, maupun berbagai pengorbanan lain [1].

\section{c. Satisfied buyer}

Hasil penelitian menunjukkan bahwa satisfied buyer di RS Tk. III Baladhika Husada Jember sudah tinggi (96,5\%). Mayoritas menyatakan tidak akan berpindah ke rumah sakit lain meskipun pelanggan mampu menanggung switching cost. Selanjutnya, mayoritas responden menyatakan bahwa pelayanan RS Tk. III Baladhika Husada Jember adalah yang terbaik. Untuk dapat 
menarik minat para pembeli yang masuk dalam tingkatan loyalitas ini maka para pesaing perlu mengatasi biaya peralihan yang harus ditanggung oleh pembeli yang masuk dalam kategori ini dengan menawarkan berbagai manfaat yang cukup besar sebagai kompensasinya (switching cost loyal) [1].

\section{d. Likes the brand}

Hasil penelitian menunjukkan bahwa likes the brand di RS Tk. III Baladhika Husada Jember sudah tinggi (92,9\%). Seluruh responden menyatakan setuju bahwa memilih rumah sakit RS Baladhika Husada Jember adalah pilihan yang tepat. Selanjutnya, mayoritas responden menyatakan sangat menyukai RS Tk. III Baladhika Husada Jember. Pada tigkatan ini dijumpai perasaan emosional yang terkait pada merek. Rasa suka pembeli bisa saja didasari oleh asosiasi yang terkait dengan simbol, rangkaian pengalaman dalam penggunaan sebelumnya baik yang dialami pribadi maupun oleh kerabatnya ataupun disebabkan oleh perceived quality yang tinggi. Meskipun demikian sering kali rasa suka ini merupakan suatu perasaan yang sulit diidentifikasi dan ditelusuri dengan cermat untuk dikategorikan ke dalam sesuatu yang spesifik [1].

\section{e. Committed buyer}

Hasil penelitian menunjukkan bahwa commited buyer di RS Tk. III Baladhika Husada Jember sudah tinggi $(89,4 \%)$. Seluruh responden menyatakan setuju bahwa ketika berobat ke RS Tk. III Baladhika Husada Jember tidak pernah merisaukan biaya rumah sakit. Selanjutnya, mayoritas responden menyatakan setuju bahwa pelanggan akan kembali ke RS Baladhika Husada Jember saat memerlukan layanan kesehatan di masa yang akan datang. Namun, sebanyak 13 responden menyatakan tidak akan kembali karena beberapa alasan yaitu pelanggan berharap tidak akan sakit yang mengharuskan pelanggan di rawat di rumah sakit. Kemudian, dalam pengambilan keputusan memilih rumah sakit, pelanggan masih mempertimbangan jenis penyakit yang dialami dengan rumah sakit yang tepat serta lokasi rumah sakit yang dekat dengan tempat tinggal. Pelanggan menyatakan bahwa pasien dirawat di RS Tk. III Baladhika Husada Jember karena rekomendasi/rujukan FKTP.

Selanjutnya, mayoritas responden sering menceritakan pengalaman berobat ke RS Tk. III Baladhika Husada Jember kepada temanteman. Namun, sebanyak 12 responden menyatakan ketidaksetujuan karena pelanggan merasa malu dan enggan untuk menceritakan kondisi penyakit pasien kepada orang lain. Kemudian, mayoritas responden akan merekomendasikan RS Tk. III Baladhika Husada Jember kepada orang lain. Namun, sebanyak 13 responden menyatakan tidak setuju karena beberapa pelangan merasa kurang puas dengan pelayanan yang diberikan dan pelanggan menganggap bahwa rumah sakit pesaing bisa memberikan pelayanan kesehatan yang lebih baik ketimbang pelayanan kesehatan yang diberikan RS Tk.III Baladhika Husada Jember.

\section{SIMPULAN DAN SARAN}

Kesimpulan pada penelitian ini berdasarkan karakteristik individu, sebagian besar responden berjenis kelamin perempuan, berada pada kelompok usia $>45$ tahun, bertempat tinggal di Jember, pendidikan terakhir tamat SD/Sederajat, pekerjaan Ibu 
Rumah Tangga (IRT), penghasilan keluarga berkisar antara Rp 1,1 Juta - Rp 2 Juta dan cara pembayaran pengobatan menggunakan asuransi BPJS Kesehatan.Variabel brand awareness sudah cukup baik karena mayoritas responden menjadikan RS Tk. III Baladhika Husada Jember sebagai puncak pikiran. Brand association melalui atribut produk, atribut tak berwujud, manfaat bagi pengguna, harga relatif, dan penggunaan/aplikasi sudah dalam kategori baik. Perceived quality melalui kinerja, pelayanan, keandalan, karakteristik produk, kesesuaian dengan spesifikasi dan hasil sudah dalam kategori baik. Brand loyalty didominasi oleh satisfied buyer.

$$
\text { Saran yang diberikan }
$$

berdasarkan hasil penelitian ini adalah RS Tk.III Baladhika Husada Jember dapat meningkatkan brand awareness melalui komunikasi pemasaran dengan memperkenalkan nama resmi RS Tk. III Baladhika Husada Jember sebagai brand rumah sakit, meningkatkan brand association dengan mengoptimalkan atribut produk rumah sakit, meningkatkan perceived quality dengan mengoptimalkan kinerja, karakteristik produk dan keandalan, serta meningkatkan brand loyalty dengan meningkatkan jumlah commited buyer melalui pelayanan kesehatan yang berkualitas setiap waktu dan berusaha memberikan kepuasan kepada pelanggan.

Untuk penelitian selanjutnya perlu dilakukan penelitian brand awareness pada masyarakat yang tidak menjalani rawat inap di RS Tk. III Baladhika Husada Jember, sehingga peneliti dapat menggali informasi brand awareness RS Tk. III Baladhika Husada Jember dari sudut pandang yang berbeda. Selanjutnya, peneliti perlu menentukan proporsi dalam pengambilan sampel disetiap kamar rawat inap. Kemudian, peneliti perlu mempertimbangkan perubahan kebijakan ekstrernal dalam perujukan pasien oleh FKTP.

\section{DAFTAR RUJUKAN}

[1] Aaker, D. A. 2013. Manajemen Pemasaran Strategis. 8th ed. Jakarta: Penerbit Salemba Empat.

[2] Abdilah, A. D. 2009. Hubungan Karakteristik Pasien Dengan Kepuasan Pasien Rawat Jalan di Puskesmas Sindangkerta Kabupaten Bandung Barat. Jurnal Kesehatan Kartika Stikes A. Yani. 4(6): 56-66

[3] Agustiani, N. 2014. Analisis Brand Equity Menurut Persepsi Pelanggan Poliklinik Anak RS Karya Bhakti. Skripsi. Bogor: Institut Pertanian Bogor.

[4] Anggraeni, A. 2008. Analisis Kualitas Pelayanan Kesehatan di Paviliun Cendrawasih RSUPN Dr. Cipto Mangunkusumo dari Sudut Pandang Manajemen, Dokter, dan Pasien. Tesis. Jakarta: Universitas Indonesia.

[5] Azwar, A. 2010. Pengantar Administrasi Kesehatan. Tangerang: Binarupa Aksara Publisher.

[6] BPJS Kesehatan. 2014. INFOBPJS Kesehatan. Edisi VI. Jakarta: Redaksi BPJS.

[7] Depkes RI, 2006. Pedoman Penyelenggaraaan dan Prosedur Rekam Medis Rumah Sakit. Jakarta: Direktorat Jendral Bina Pelayanan Medik.

[8] Dinas Kesehatan Kabupaten Jember. 2014. Profil Kesehatan Kabupaten Jember Tahun 2014. 
Jember: Dinas Kesehatan Kabupaten Jember.

[9] Djohan, A. J. 2015. Faktor-Faktor yang Mempengaruhi Kepuasan dan Kepercayaan untuk Mencapai Loyalitas Pasien Rawat Inap pada Rumah Sakit Swasta di Kota Banjarmasin. Jurnal Aplikasi Manajemen (JAM). 13(2).

[10] Fatma, N. E. 2014. Analisis Desain Wayfinding berdasarkan Aspek Ergonomi di RSUD Karanganyar. Jurnal Rekam Medis. 8(2): 59-66.

[11] Gunarsa, S. 2008. Psikologi Perawatan. Jakarta: Gunung Mulia.

[12] Hatmoko, A. U. 2011. Arsitektur Rumah Sakit. Yogyakarta: PT Global Rancang Selaras.

[13] Hirtanto, T. 2008. Analisis Kebutuhan Parkir Pada Rumah Sakit Umum Kelas B Di Kota Semarang. PILAR. 15(1):51-59

[14] Husin, L. 2004. Hubungan Persepsi Jarak Ke Puskesmas Dengan Tingkat Kepuasan Pasien Terhadap Pelayanan BP Umum Puskesmas di Kota Palembang Tahun 2004. Skripsi. Depok: Universitas Indonesia.

[15] Justisiani E. I. 2014. Persepsi Masyarakat Tentang Bentuk Komunikasi Verbal Dan Komunikasi Nonverbal Pada Pelayanan Rumah Sakit Umum Daerah Abdul Wahab Sjahranie Samarinda. Jurnal Ilmu Komunikasi. 2(3): 193-206.

[16] Kementrian Kesehatan Republik Indonesia. 2012. Pedoman Teknis Bangunan Rumah Sakit Ruang Rawat Inap. Jakarta: Kementerian Kesehatan Republik Indonesia

[17] Kementrian Kesehatan Republik Indonesia. 2016. Profil Kesehatan Indonesia Tahun 2015. Jakarta: Kementerian Kesehatan Republik Indonesia.
[18] Kotler, P., Shalowitz, J., dan Stevens, R. 2008. Strategic Marketing For Health Care Organizations: Building A Customer-Driven Health System. San Francisco: JosseyBass.

[19] Kurniawan, A. 2012. Pengaruh Karakteristik Pasien Terhadap Indeks Kepuasan Masyarakat Tentang Pelayanan Rawat Jalan Puskesmas Banyumas. Jurnal Kesmasindo. 5(2): 169-179.

[20] Laurencia, S. 2017. Pengaruh Repositioning Sour Sally Terhadap Brand Equity Sour Sally. Skripsi. Bandung: Universitas Katolik Parahyangan.

[21] Maharani, D. N. 2016. Analisis Pengaruh Kepuasan Pasien Terhadap Kualitas Pelayanan Resep Di Apotek Instalasi Farmasi Badan Rumah Sakit Daerah Luwuk Kabupaten Banggai. GALENIKA Journal of Pharmacy. 2(2):111-117.

[22] Nurlia, C. 2012. Hubungan Bauran Pemasaran Dengan Keputusan Pasien Rawat Inap Memilih Layanan Kesehatan Di Rumah Sakit Islam Faisal Makassar Tahun 2011. Jurnal AKK. 1(1): 15-21.

[23] Nursalam. 2014. Manajemen Keperawatan: Aplikasi dalam Praktik Keperawatan Profesional. 4th ed. Jakarta: Salemba Medika.

[24] Nurulaini, N. 2010. Analisa Brand Equity Rumah Sakit Islam Jakarta Menurut Persepsi Pelanggan Rawat Jalan di Empat Layanan Dasar pada Tahun 2010. Tesis. Jakarta: Fakultas Kesehatan Masyarakat Universitas Indonesia.

[25] Pamungkas, F. 2016. Pengalaman Pasien Dirawat Inap di Rumah Sakit sebagai Upaya Penyusunan Strategi Pemasaran. Jurnal Aplikasi Manajemen (JAM). 14(1):109-119. 
[26] Priyadi. 2015. Manajemen Rumah Sakit Menghadapi Era Masyarakat Ekonomi Asean Tahun 2015. http://www.indonesianqualityawa rd.org/baldrige-berdasarkansektor/health-care/manajemenrumah-sakit-menghadapi-eramasyarakat-ekonomi-asean-th2015\#.WT2GPNyyTIU[Diakses pada 11 Juni 2017].

[27] Rahmayanti, S. N. 2017. Karakteristik Responden dalam Penggunaan Jaminan Kesehatan Pada Era BPJS di Puskesmas Cisoka Kabupaten Tangerang JanuariAgustus $2015 . \quad J u r n a l$ Mediocoeticolegal dan Manajemen Rumah Sakit. 6(1): 61-65.

[28] Rusydi, A. R. 2011. Analisis Faktorfaktor yang Membentuk Ekuitas Merek Rumah Sakit Tadjuddin Chalid Makassar. Jurnal Media Kesehatan Masyarakat Indonesia. 6(2): 133-140.

[29] Sangadji, E. M. dan Sopiah. 2013. Perilaku Konsumen: Pendekatan Praktis Disertai Himpunan Jurnal Penelitian. Yogyakarta: Penerbit Andi.

[30] Sayekti, I. 2013. Bel Pemanggil Perawat Berbasis Wireless Menggunakan Xbee. Jurnal Teknik Elektro Terapan. 2(3): 174-180.

[31] Supartiningsih, S. 2017. Kualitas Pelayanan Kepuasan Pasien Rumah Sakit: Kasus Pada Pasien Rawat Jalan. Jurnal Medicoeticolegal dan Manajemen Rumah Sakit. 6 (1): 915.

[32] Supriyanto, S. dan Ernawaty. 2010. Pemasaran Industri Jasa Kesehatan. Yogyakarta: Penerbit Andi.
[33] Susanto, J. 2011. Perancangan Taman Sebagai Penunjang Aktivitas Rumah Sakit Di R.S. Dr. H. Marzoeki Mahdi, Bogor. Skripsi. Bogor: Departemen Arsitektur Lanskap Fakultas Pertanian Institut Pertanian Bogor.

[34] Tarmedi, E. 2009. Pengaruh Perceived Quality Dari Brand Equity Terhadap Keputusan Pembelian Deterjen Bukrim. Jurnal Pendidikan Manajemen Bisnis (Strategic). 8(15): 36-100.

[35] Tjiptono, F. 2011. Manajemen \& Strategi Merek. Yogyakarta: Penerbit Andi.

[36] Ummah, A. R. 2014. Analisis Mutu Pelayanan Kesehatan Berdasarkan Dimensi Dabholkar Di Paviliun Mina Rumah Sakit Siti Khodijah Sepanjang. Jurnal Administrasi Kesehatan Indonesia. 2(1): 1-13.

[37] Undang-undang Republik Indonesia Nomor 36 Tahun 2009. Kesehatan. 13 Oktober 2009. Lembaran Negara Republik Indonesia Tahun 2009 Nomor 114.

[38] Wulandari, F. 2016. Hubungan Antara Komunikasi Dokter-Pasien Dengan Kepuasan Pasien Rawat Inap Di Rsud Sukoharjo. Skripsi. Solo: Universitas Muhammadiyah Surakarta.

[39] Yunida, M.E. 2016. Garuh Citra Rumah Sakit Dan Kualitas Pelayanan Terhadap Loyalitas Pelanggan Melalui Kepuasan Pelanggan Di Rumah Sakit Amal Sehat Wonogiri. Jurnal Manajemen Bisnis Indonesia (JMBI). 5(3):287297. 